\title{
Side Light: @deusludens. A Twitter Thread
}

I am the Lord of the play. I created you by teasingly blowing into your nostrils. Ever since you came to life, we have playfully interacted, genesising together, enjoying the becoming of things, forms, the world. Stop questioning if I exist or not. I become real as we play $1 / 10$

I created you in my image and likeness; you are a playing species. The fun is that as you ludically transform elementary actions into something beyond survival, you make sense of the world. What is play except finding truth? What other than humankind's perpetual becoming? 2/10

No, play isn't always fun. After that forbidden-fruit-affair you often quit our play, starting your own games, ready to decide (in my name) who was out, who had lost the right to play along, who knew the rules. Your inclination to act as game leader can be slightly tiresome $3 / 10$

Verily, mixed feelings were always part of play, both in Jesus' crucifixion (my most ludic move) and in 21st century digital play. Jesus died for you to live in my reality. Scroll your way through his Passion and feel uneasy, o denizens of teh interwebz: confusion is vital $4 / 10$

BTW, the playfulness of Web 2.0 and socials are closer to me than you might think. The virtual ('non-tangible' like me) and the real are connected, on the internet as in Jesus. Your multisensory digital experiences are incarnate stuff that playfully tie me to your world 5/10

Corrupted play - Auschwitz, Aleppo, all evil - remains play. Play is tricky for you as it is for me. You may cheat. You have cheated. If I lose my credibility you may want to quit. Do me a favour: unless lives are at risk, seek lightness, don't take yourselves too seriously $6 / 10$

Playfulness gives life in abundance, Mary knows why! But was her delight in me but enthusiastic foreplay for a cruel game of high stakes poker on the cross? There, going all-in was matched by what? Darkness? The game is on, graciously, you're playing the role of your life! $7 / 10$

Our play combines two worlds: the reality you live in and my world-to-come. Whenever you encounter people giggling, laughing, dancing, musicking, jok- 
ing, storytelling, protesting, feast your eyes! Their play may perform a seethrough perspective on my envisioned kingdom $8 / 10$

I still let you play for a bit, but on my day, there will be an Everlasting Closing Party. Humour, improvisation and 'oh and ah' will abound. There will be royal entertainment transcending the joy of any other play. Jest to experience a foretaste of my grand finale $9 / 10$

Lastly: I playingly imagined our play, y'all. These rules are not set in stone I am open to negotiation and may even embrace criticism, lol. Come on, let me know what you think. Cheerz! \#slowthread \#homoludens2.o \#deusludens \#divineplay \#10x280characters \#discuss 10/10 